\title{
Comparison of microbial isolates isolated from external ear canal of sheep and their susceptibility to antibiotics
}

\author{
Sahar Mahdi Hayyawi \\ Department of Microbiology, College of Veterinary Medicine University of Baghdad, \\ Baghdad, Iraq
}

\section{Summary}

One hundred sheep with bilateral otitis externa were studied one year and a half.The exudates of both external ears obtained using sterile swabs, and microorganisms were isolated according to standard microbiological techniques. There was bacterial and fungal growth in many of the samples. The total numbers of isolates from right ear was 104 , and the most common pathogens isolated in right ear were Staphylococcus aureus $30.76 \%$, then Staphylococcus epidermidis $9.61 \%$ and Pseudomonas aeruginosa $9.61 \%$ while E.coli , Proteus mirabilis and Streptococcus pyogenes were $7.69 \%$ for each of them , Candida albicans 5.76\%, Klebsiella pneumonia 3.84\% ,Nocardia spp 3.84\%, Pasteurella multucida 3.84\%, Mannheimia haemolytica 3.84\%, Aspergillus spp. $3.84 \%$ and Streptomyces spp. $1.23 \%$. The total number of isolates from left ear was 96 ,the most pathogens were Staphylococcus aureus $27.08 \%$ while Pseudomonas aeruginosa $12.5 \%$ and Streptococcus pyogenes were $12.5 \%$, Klebsiella pneumonia $8.33 \%$ and Proteus mirabilis $8.33 \%$, Staphylococcus epidermidis, Nocardia spp $6.25 \%$, then Streptomyces spp, Pasteurella multucida and Mannheimia haemolytica were 4.16\%, the last E.coli, Aspergillus spp and Candida albicans were $2.08 \%$ for each of them. The result were showed significant differences at level $\mathrm{P}<0.05$ between bacteria and fungi isolates, and have no significant differences at level $\mathrm{P}>0.05$ between right and left ear. High susceptible rates of gram positive Staphylococcus aureus to (Amoxicillin + Clavulaunic acid) and Chloramphenicol were $100 \%$, while high susceptible rates of gram negative Pseudomonas aeruginosa was $90.90 \%$ to Ciprofloxacin, (Amoxicillin+ Clavulaunic acid) and Chloramphenicol .

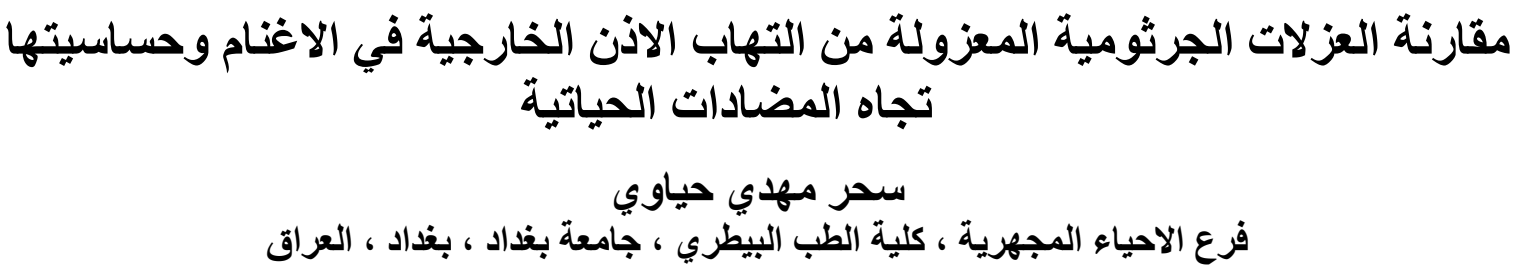

الخلاصة

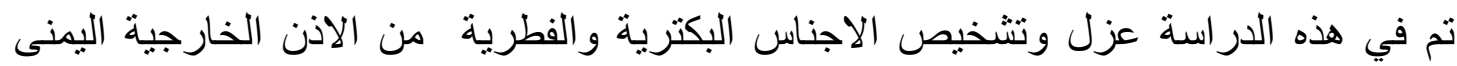

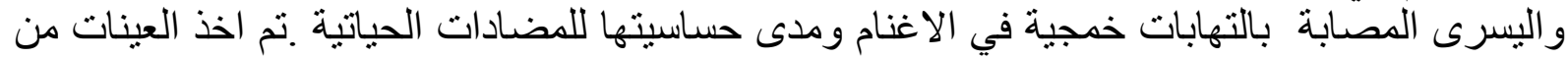

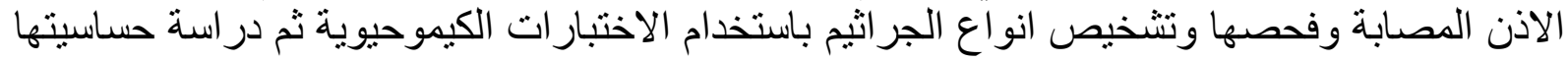

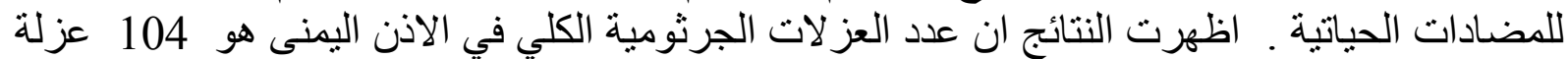

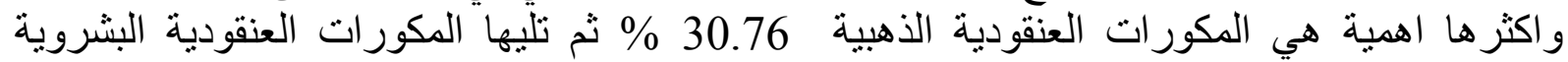
و الزوائف الزنجارية 9.61 \% \% لكل منها ، تليها الاشريشيا القولونية والمتقلبات و المسبحيات القية القيحية

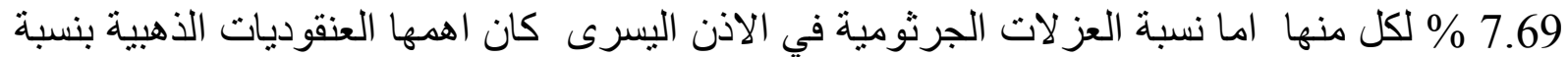

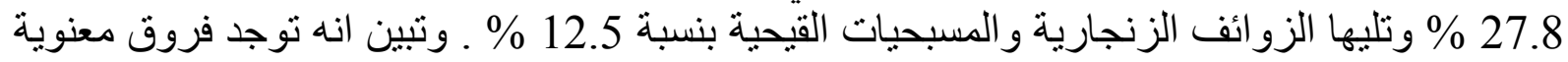

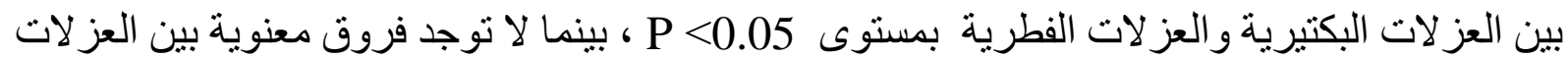

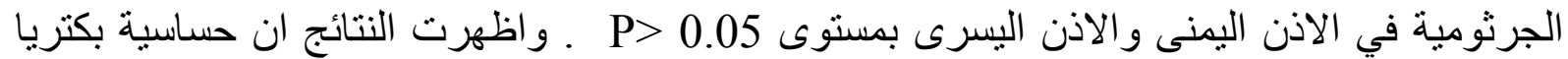
العنقوديات الذهبية تجاه (الاموكسلين+حامض الكلافيولونك اسد و الكلور امفينيكول كان بنسبة 100 \%

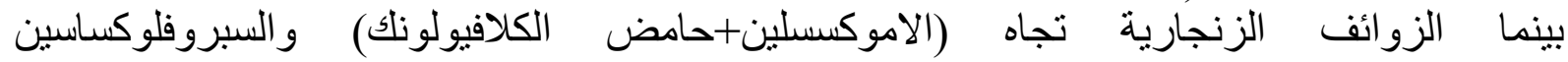
و الكلور امفينيكول كان بنسبة 90.90 \% 


\section{Proceeding of the Eleventh Veterinary Scientific Conference, 2012; 41-48}

\section{Introduction}

Otitis externa is similar to skin and soft tissue infection elsewhere. Two major type of external Otitis: acute and chronic; acute external otitis may be localized or diffuse .Acute localized disease occurs in the form of a pustule or furuncle and typically result from Staphylococcus aureus. Erysipelas caused by group A streptococci may involve the external ear canal and the soft tissue of the ear itself (1). The normal flora of external ear are rather sparse, similar to flora of the conjunctival sac qualitatively except pneumococci, Staphylococcus aureus and Enterobacteriacae, Pseudomonas aeruginosa and non-Candida albicans (2). Many factors can predispose sheep and goat to Otitis externa, the first is the anatomic orientation of the ear canal itself and cause an inflammation of the outer ear and ear canal (3). Otitis externa has multifactorial etiology and bacteria play an important role in otic diseases $(3,4)$ lesions on ear pain, balance alterations, itch, hemorrhagic lesions, ear orifice surrounding mucous discharge yellowish in color (5). These are clinical signs of significance in most cases and may indicate the presence of pathogenic infections $(6,7)$. Many studies have used samples collected from only one ear per animal (8), others have used samples collected from 1 or both ears and considered them as different samples (9).The purpose of this study was bacterial and fungal isolation patterns of samples collected from both ears to study the antimicrobial susceptibility pattern on the prevalent strains.

\section{Material and Methods}

Hundred samples were taken from infected ear of sheep ,right and left ears from the Veterinary Clinic farms around veterinary college in Baghdad, the age between 6 months -2 years old, in this study both numbers of female and male were 50 . Both ears swabbed by sterile cotton swabs then inoculated in nutrient broth as a primary bacterial isolation and incubated at $37{ }^{\circ} \mathrm{C}$ for 24 hours after that cultured by streaking method on MacConkey agar then incubated aerobically at 37( 10)+ , while blood agar under $\mathrm{CO}_{2}$ condition for 24 hours (11). Routine bacterial culture was performed in all samples , then made the biochemical test to identified bacterial species, also the fungus were isolated by Sabaouroaud dextrose agar (12). For sensitivity test we have prepared Sterile Muller Hinton agar media then poured in sterile petri plates under aseptic condition used for susceptibility of antibiotic sensitivity disc. $(13,14)$ included; Ampicillin, Amikacin, Clarithromycin, Gentamycin , Amoxicillin, Ciprofloxacin, Cefotaxime, Augmantin, Trimethoprim + Sulfamethoxazol and Chloramphenicol.

The values were considered statistically significant ANOVA (Analysis of variance) for least significant differences (15).

\section{Results}

The result were showed that there was significant differences at level $\mathrm{P}<0.05$ between bacterial and fungal isolates, the total number of bacterial and fungal species isolated from right external ear canal was 104 included : Staphylococcus aureus the most prevalent $30.76 \%$,followed by Staphylococcus epidermidis and, Pseudomonas aeruginosa, $9.61 \%$ for each of them, but E.coli, Proteus mirabilis, Streptococcus pyogenes were $7.69 \%$ for each of them, while Candida albicans $5.76 \%$, then Klebsiella pneumonia, Nocardia spp. Pasteurella multucida, Mannheimia haemolytica Aspergillus spp were 3, $84 \%$ for each of them, the last Streptomyces spp was $1.23 \%$. The total number of isolates from left ear was 96 included : Staphylococcus aureus $27.8 \%$, Pseudomonas aeruginosa, Streptococcus pyogenes $12.5 \%$ per each, while Klebsiella pneumonia, and Proteus mirabilis 8,33\%, then Staphylococcus epidermidis , Nocardia spp 6.25\%, Streptomyces spp, Pasteurella multucida and Mannheimia haemolytica were 4.16\%, the last E.coli, Aspergillus spp and Candida albicans were $2.08 \%$ per each (table 1,2 ). There were no significant differences at $\mathrm{P}>0.05$ between right and left infected ear.

The results of antibiotic sensitivity test to bacterial isolates from otitis externa in sheep showed that Mannheimia haemolytica have been a significant differences at level $\mathrm{P}<0.05$ 
Proceeding of the Eleventh Veterinary Scientific Conference, 2012; 41-48

among different antibiotics, the highest were Amikacin , Gentamycin, ciprofloxacin, Augmantin and Chloramphenicol have 100\% and the lowest was Ampicillin (table -8) .

Table 1: Numbers of bacteria and fungus species isolates from infected right ear in sheep

\begin{tabular}{|l|c|c|}
\hline $\begin{array}{l}\text { Bacterial isolation from right } \\
\text { ear }\end{array}$ & $\begin{array}{l}\text { Number of } \\
\text { isolates from right } \\
\text { ear }\end{array}$ & Percentage \% \\
\hline Staphylococcus aureus & 32 & $\mathbf{3 0 . 7 6}$ \\
\hline Staphylococcus epidermidis & $\mathbf{1 0}$ & $\mathbf{9 . 6 1}$ \\
\hline Pseudomonas aeruginosa & $\mathbf{1 0}$ & $\mathbf{9 . 6 1}$ \\
\hline Escherichia coli & $\mathbf{8}$ & $\mathbf{7 . 6 9}$ \\
\hline Proteus mirabilis & $\mathbf{8}$ & $\mathbf{7 . 6 9}$ \\
\hline Streptococcus pyogenes & $\mathbf{8}$ & $\mathbf{7 . 6 9}$ \\
\hline Candida albicans & $\mathbf{6}$ & $\mathbf{5 . 7 6}$ \\
\hline Klebsiella pneumonia & 4 & $\mathbf{3 . 8 4}$ \\
\hline Nocardia spp. & 4 & $\mathbf{3 . 8 4}$ \\
\hline Pasteurella multucida & 4 & $\mathbf{3 . 8 4}$ \\
\hline Mannheimia haemolytica & 4 & $\mathbf{3 . 8 4}$ \\
\hline Aspergillus spp. & 4 & $\mathbf{3 . 8 4}$ \\
\hline Streptomyces spp. & 2 & $\mathbf{1 . 2 3}$ \\
\hline & & \\
\hline
\end{tabular}

Table 2: Numbers of bacteria and fungus species isolates from infected

Left ear in sheep

\begin{tabular}{|l|c|c|}
\hline $\begin{array}{c}\text { Bacterial isolation from left ear } \\
\text { infected }\end{array}$ & $\begin{array}{l}\text { Number of } \\
\text { isolates from left } \\
\text { ear }\end{array}$ & Percentage \% \\
\hline Staphylococcus aureus & 26 & 27.08 \\
\hline Pseudomonas aeruginosa & 12 & 12.5 \\
\hline Streptococcus pyogenes & 12 & 12.5 \\
\hline Klebsiella pneumonia & 8 & 8.33 \\
\hline Proteus mirabilis & 8 & 8.33 \\
\hline Staphylococcus epidermidis & 6 & 6.25 \\
\hline Nocardia spp & 6 & 6.25 \\
\hline Streptomyces spp. & 4 & 4.16 \\
\hline Pasteurella multucida & 4 & 4.16 \\
\hline Mannheimia haemolytica & $\mathbf{4}$ & 4.16 \\
\hline Escherichia coli & 2 & 2.08 \\
\hline Aspergillus spp. & 2 & 2.08 \\
\hline Candida albicans & & 2.08 \\
\hline & total & \\
\hline
\end{tabular}

The high percentage of gram positive bacterial isolates from right ear was Staphylococcus aureus $61.5 \%$ (table-3). 
Proceeding of the Eleventh Veterinary Scientific Conference, 2012; 41-48

Table 3: Numbers of gram positive bacteria from infected right ear in sheep

\begin{tabular}{|c|c|c|}
\hline Gram- Positive Bacteria & $\begin{array}{l}\text { Number of isolates } \\
\text { from right ear }\end{array}$ & $\%$ Percentage \\
\hline Staphylococcus aureus & 32 & 61.5 \\
\hline Staphylococcus epidermidis & 10 & 19.2 \\
\hline Streptococcus pyogenes & 8 & 15.38 \\
\hline Streptomyces spp. & 2 & 3.84 \\
\hline & 52 total & \\
\hline
\end{tabular}

Table 4: Numbers of gram positive bacteria from infected left ear in sheep

\begin{tabular}{|l|c|l|}
\hline Gram- Positive Bacteria & $\begin{array}{l}\text { Number of isolates } \\
\text { from left ear }\end{array}$ & Percentage \% \\
\hline Staphylococcus aureus & 26 & 54.16 \\
\hline Streptococcus pyogenes & 12 & 25 \\
\hline Staphylococcus epidermidis & 6 & 12.5 \\
\hline Streptomyces spp. & 4 & 8.33 \\
\hline & & \\
\hline
\end{tabular}

The most gram negative bacteria isolated from right ear was Pseudomonas aeruginosa $26.315 \%$ (table -5), while in the left ear was $26.315 \%$ (table- 6).

Table 5: Numbers of gram negative bacteria from infected right ear in sheep

\begin{tabular}{|l|c|c|}
\hline Gram- negative bacteria & $\begin{array}{l}\text { Number of isolates } \\
\text { from right ear }\end{array}$ & Percentage \% \\
\hline Pseudomonas aeruginosa & 10 & 26.3 \\
\hline Escherichia coli & 8 & 21.05 \\
\hline Proteus mirabilis & 8 & 21.05 \\
\hline Klebsiella pneumonia & 4 & 10.5 \\
\hline Pasteurella multucida & 4 & 10.5 \\
\hline Mannheimia haemolytica & 4 & 10.5 \\
\hline & & 38 total \\
\hline
\end{tabular}


Proceeding of the Eleventh Veterinary Scientific Conference, 2012; 41-48

Table 6: Numbers of gram negative bacteria from infected left ear in sheep

\begin{tabular}{|l|c|l|}
\hline Gram- negative bacteria & $\begin{array}{c}\text { Number of } \\
\text { isolates from } \\
\text { left ear }\end{array}$ & Percentage \% \\
\hline Pseudomonas aeruginosa & 12 & 31.5 \\
\hline Klebsiella pneumonia & 8 & 21.05 \\
\hline Proteus mirabilis & 8 & 21.05 \\
\hline Pasteurella multucida & 4 & 10.5 \\
\hline Mannheimia haemolytica & 4 & 10.5 \\
\hline Escherichia coli & 2 & 5.26 \\
\hline & & \\
\hline
\end{tabular}

Table:7 Biochemical tests were include: Biochemical test for bacterial species isolates from otitis externa in sheep

\begin{tabular}{|c|c|c|c|c|c|c|c|c|c|c|}
\hline $\begin{array}{l}\text { Bacterial } \\
\text { species }\end{array}$ & SIM & catalase & oxidase & Coagulase & pigments & MR & VP & SC & $\begin{array}{l}\text { Urea } \\
\text { hydrolysis }\end{array}$ & TSI \\
\hline $\begin{array}{l}\text { Staphylococcus } \\
\text { aureus }\end{array}$ & $\cdots$ & + & - & + & Yellow & & + & I & + & I \\
\hline $\begin{array}{l}\text { Staphylococcus } \\
\text { epidermidis }\end{array}$ & $\cdots$ & + & - & - & White & & + & I & + & I \\
\hline $\begin{array}{l}\text { Pseudomonas } \\
\text { aeruginosa }\end{array}$ & --+ & + & + & I & Green & & & + & + & K / K \\
\hline $\begin{array}{l}\text { Escherichia } \\
\text { coli }\end{array}$ & -+- & + & - & I & I & + & - & - & - & $\begin{array}{ll}\mathbf{Y} / & \mathbf{Y} \\
\text { gas+ } & \end{array}$ \\
\hline $\begin{array}{l}\text { Proteus } \\
\text { mirabilis }\end{array}$ & +-+ & + & - & I & I & + & - & + & + & $\begin{array}{ll}\mathbf{K} \quad / & \mathbf{A} \\
\mathbf{H} 2 \mathrm{~S}+ & \end{array}$ \\
\hline $\begin{array}{l}\text { Streptococcus } \\
\text { pyogenes }\end{array}$ & $\cdots$ & - & - & I & I & I & I & I & I & I \\
\hline $\begin{array}{l}\text { Klebsiella } \\
\text { pneumonia }\end{array}$ & $\cdots$ & + & - & 1 & mucoid & - & + & + & + & $\begin{array}{ll}\mathbf{A} / & \mathbf{A} \\
\text { gas }+ & \end{array}$ \\
\hline $\begin{array}{l}\text { Pasteurella } \\
\text { multucida }\end{array}$ & $I+I$ & + & + & I & I & & & & - & I \\
\hline $\begin{array}{l}\text { Mannheimia } \\
\text { haemolytica }\end{array}$ & $I-I$ & + & + & I & I & & & & - & I \\
\hline $\begin{array}{l}\text { Streptomyces } \\
\text { spp. }\end{array}$ & & - & & I & $\begin{array}{l}\text { branching } \\
\text { Arial } \\
\text { filament }\end{array}$ & I & I & & \pm & 1 \\
\hline
\end{tabular}

SIM= sulfur Indole Motility, MR=methyl red, $\mathrm{VP}=$ vogues proskaour, $\mathrm{SC}=$ Simmoncitrate, $\mathrm{TSI}=$ Triple sugar iron 


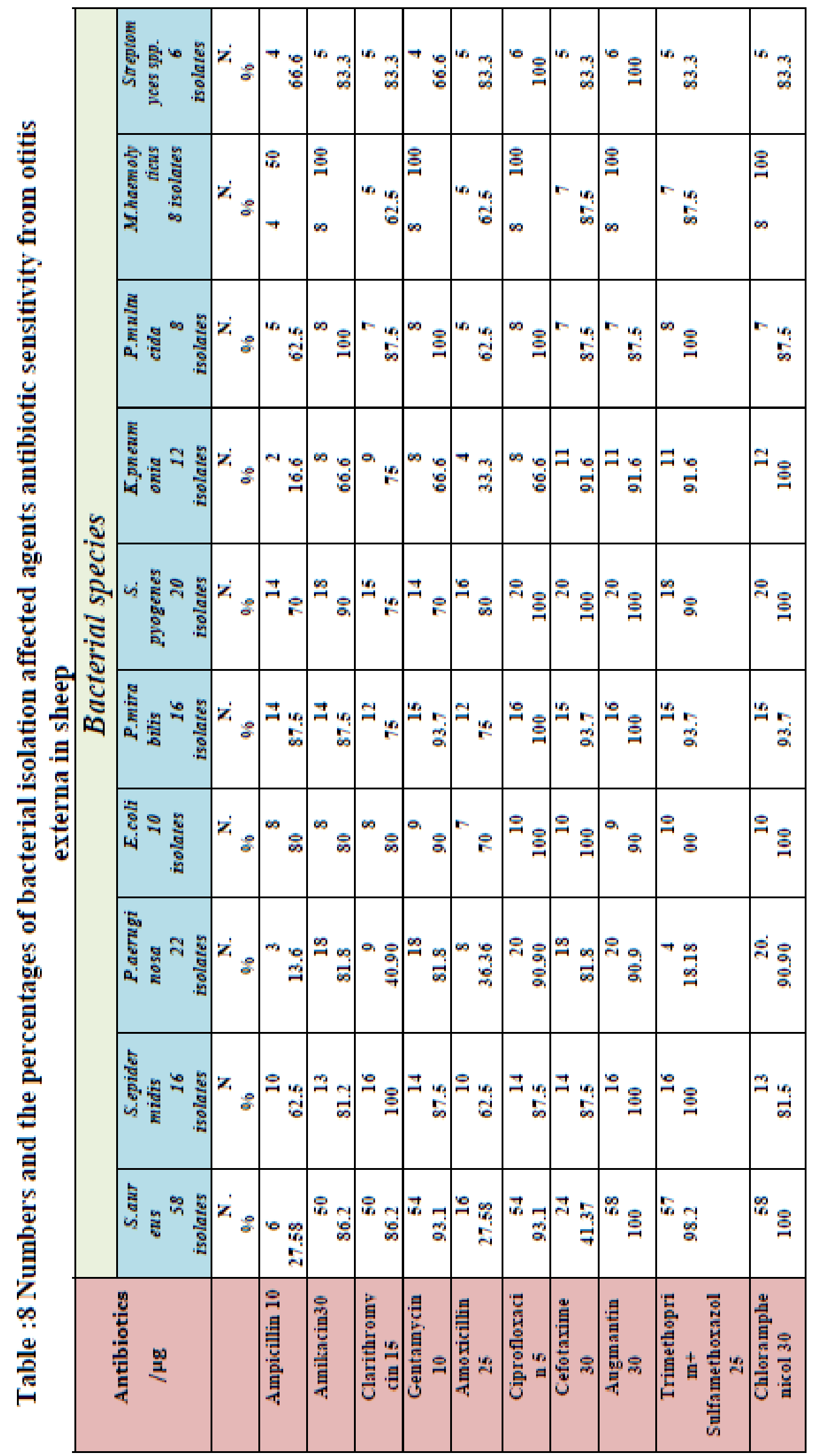




\section{Proceeding of the Eleventh Veterinary Scientific Conference, 2012; 41-48}

\section{Discussion}

The purpose of this study to determine the isolation and identification of bacterial and fungal species and antibacterial susceptibility test then compare this isolation pattern from both ears in bilateral otitis externa in sheep. Ear infection in calves and lambs has been associated with concurrent respiratory diseases, also the otitis in goat and sheep compared with the information on cattle and horses (16). the skin lining of the external ear canal has a large numbers of gland, these include modified porcine gland which produce large amounts of secretions which provide good suitable media for irritation and infection (1). The result appears that the total numbers in right infected ears were 104 isolates, while in left ears were 96 isolates, the result have no significant differences at $\mathrm{P}>0.05$ between right and left infected ears. Many microbial infections commonly inhibit the ear canal and can become secondary opportunistic invaders when conditions are favorable (5). And it probably ascended from the pharynx through the auditive tube into the tympanic cavities (17). The most importance gram positive pathogenic bacteria was Staphylococcus aureus that isolated from both ears, while the most one of gram negative bacteria was pseudomonas aeruginosa (5). As expected, low level of sensitive to Ampicillin $27.58 \%$ was observed because of the $\beta$ - lactamase enzyme produced by Staphylococcus aureus similar to that described in the literature (18, 19, and 20). Pseudomonas aeruginosa is this study sensitive to Ciprofloxacin, Augmantin and Chloramphenicol $90.90 \%$. Also polymyxin B ticarcillin , or enrofloxacin, polymyxin B is inactivated by purulent debris and must be applied only in clean ears (21), either acetic acid $2 \%$ is effective against Pseudomonas after 1 minute of contact time, higher concentrations of acetic acid may be irritating ,aluminum acetate is also effective against Pseudomonas when used topically(22). Ear medications are applied after cleaning and drying ,and is usually in form of ointment applied daily or twice daily for one or two weeks and the type of infection must be identified by the veterinarian by examining a sample of ear exudates under a microscope, since bacterial infection will only respond to antibiotics, fungal infection to a fungicide (23).

Management of chronic recurrent otitis externa requires diagnosis and control of predisposing factors with oral and topical antimicrobials.

\section{References}

1- Thibodeau , G. A. and Patton, K.T. (1993).Anatomy and physiology. $2^{\text {nd }}$.St Louis, Mosby .

2-Betty, A.F.; Daniel, F.S. and Alice, S.W. (2007). Diagnostic Microbiology 12 ed Mosby Inc .,an affiliate of Elsevier Inc .56:837

3-Pugh, D.G. (2000). Sheep and Goat Medicine . $4^{\text {th }}$ ed. Philadelphia : WB Saunders Com.

4-Ismail, S. F.(1994) . Studies on some surgical affections of the external ear in farm animals .Assuit Vet Med J 32:177-187

5-Harry, H.; Mada, C. and Rober, P. (2006). Update on antimicrobial susceptibilities bacterial isolates from canine and feline Otitis externa. Can Vet J 47:253-255.

6-Duarte, E.R. and Hamdan, J.G. (2004). Otitis in cattle, An etiology review .J.Vet. Med 5:1-7.

7-Yeruham ,D. and Elad, M. L. (1999) . Clinical and Microbiological study of an Otitis Media outbreak in Calves in dairy herd J Vet Med 46:145-150

8-Lilenbaum, W.; Veras, M ; Blum, E. and Souza, G.N. (2000) . Antimicrobial susceptibility of Staphylococci isolated from Otitis in dogs Lett Appl Microbiology 31:4245.

9 -Barrasa , J.L.M .; Gomez, P.L .; Lama, Z.G. and Junco, M.T. (2000) . Antibacterial susceptibility pattern of Pseudomonas strains isolated from chronic canine Otitis externa $\mathbf{J}$ Med Vet B 47:191-196 


\section{Proceeding of the Eleventh Veterinary Scientific Conference, 2012; 41-48}

10- Cater, G.R. and Chengappa , M.M. (1993) . Microbial diseases. A Veterinarians Guide to laboratory diagnosis. Ames Iowa state University press $1 \mathrm{pp}$ : 65-66 .

11-Quinn,P.J.; Carter, M.E.; Markey, B. and Carter, G.R. (1994) . Clinical Veterinary Microbiology .London :Wolfe , Mosby pp: 95-101 .

12-Koneman, E.W.; Stephan ,D.A. ; Dowell, J.R.and Somers, S.M. (1983). Color Atlas and textbook of Diagnostic Microbiology. Philadelphia: Lippincott

13 -Jorgensen, J.H; Turnidge , J.D. and Washington, J.A.(1999) . Antibacterial Susceptibility test dilution and disk diffusion methods in manual of clinical Microbiology , 7 th . ed .ASM press, Washington.D.C.pp:152-1543

14- Baure, A.W.; Kirby,W.M. ; Sherris, J.C. and Turck, M.(1966).Antibiotic susceptibility testing by a standarized single disk method. Am.J.Chem. pathol.95 :493-49. 15 -Snedecor,G.W. and Cochran,W.G.(1968) . Statistical Methods .Iowa State Uni.Press .

16 -Opal ,S.; Cross, A. and Gemsk, I. P.K. (1982) . Antigen and serum sensitivity of rough Escherichia coli infect Immun 37;956-960

17 -Jensen, R.; Pierson, R.E. ; Weibel, J.L.;Tucker, J.O. and Swift, B.L. (1982) . Middle ear infection in feedlot lambs, J Am Vet Med Assoc 181; 805-807.

18-Lilenbaum, W.; Veras, M.; Blum ,E.and Souza, G.N.(2000). Antimicrobial susceptibility of Staphylococci isolated from otitis externa in dogs. Let Appl Microbiology.31; 42-45

19 - Hariharan, H.; Coles, M.; Poole, D.; Lund, I. and Page, R. (2006) Update on antimicrobial susceptibilities of bacterial isolates from canine and feline otitis externa . Can Vet J ,47:253-255.

20 -Farwachi, M. I. and Hassan, M .M. (2008) .Clinical and microbiological study of otitis externa in sheep .Iraqi journal of Vet Sci ,Vol. 22 ,No.1: 43-48.

21 -Logas, D.B. (1994) . Diseases of ear canal .Vet Clin North Am Small Anim Pract 24: 905-919.

22 - Teresa, C. and DeManuelle. (2001).Advances in the treatment of Chronic Otitis Externa and Media in the dog. Bayer Selected Proceeding, TNAVC, January.

23-Shimizo, A.; Wakita ,Y.; Nagase, S. et al.(2001) .Antimicrobial susceptibility of Staphylococcus intermedius isolated from healthy and diseased dogs . J Vet. Med Sci ; 63 ;357-360. 